\title{
AUTOMATION OF CHAMPAGNE WINES PROCESS IN SPARKLING WINE PRESSURE TANK
}

${ }^{1}$ Lukyanchuk E.V., ${ }^{1}$ KhobinV.A.

${ }^{1}$ Odessa National Academy of Food Technologies, Odessa

E-mail: ${ }^{\text {jack94q@mail.ru }}$

Copyright (C 2014 by author and the journal "Automation technological and business - processes". This work is licensed under the Creative Commons Attribution International License (CC BY). http://creativecommons.org/licenses/by/4.0/

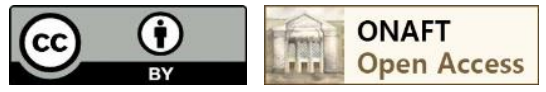

DOI: $10.15673 /$

\begin{abstract}
The wine industry is now successfully solved the problem for the implementation of automation receiving points of grapes, crushing and pressing departments installation continuous fermentation work, blend tanks, production lines ordinary Madeira continuously working plants for ethyl alcohol installations champagne wine in continuous flow, etc. With the development of automation of technological progress productivity winemaking process develops in the following areas: organization of complex avtomatization sites grape processing with bulk transportation of the latter; improving the quality and durability of wines by the processing of a wide applying wine cold and heat, as well as technical and microbiological control most powerful automation equipment; the introduction of automated production processes of continuous technical champagne, sherry wine and cognac alcohol madery; the use of complex automation auxiliary production sites (boilers, air conditioners, refrigeration unitsand other.); complex avtomatization creation of enterprises, and sites manufactory bottling wines. In the wine industry developed more sophisticated schemes of automation and devices that enable the transition to integrated production automation, will create, are indicative automated enterprise serving for laboratories to study of the main problems of automation of production processes of winemaking.
\end{abstract}

Keywords

Automation, system akratofor, management, task, modeling.

\section{Introduction}

The essence of the production process - fermentation of wine materials . This anaerobic (which occurs without oxygen) metabolic breakdown of nutrient molecules, such as glucose. Considered method involves fermentation in stainless steel, glasslined tanks or other containers that can withstand the necessary pressure.

In the world there are various methods of producing sparkling wines. Consider a few examples.

For example, the automatic control of the process of fermentation wine material using the method Shossepe, temperature control akratofor occurs by changing the refrigerant flow in the spiral coil. [ "Sparkling wines" SP Avakyants]

In the automatic process control using raw wine fermentation method Sharma akratofors temperature regulation takes place by changing the refrigerant flow. [ "Sparkling wines" SP Avakyants]

Also known method of automatic control of fermentation process raw wine where temperature regulation takes place by changing akratofor refrigerant flow into the jacket through the valve and akratofor refrigerant feed pump. Also stabilized at a predetermined level value of the coolant temperature by changing the speed of the compressor.

[ "Sparkling wines" SP Avakyants]

The disadvantage of these methods is that they do not provide a wine base akratofor pressure control, which gives a low quality of the final product.

Therefore, this process needs to be focused on the impact, so you can select the next target in the process control akratofor

prevent release of the limit values of process parameters, namely:

- Temperature of the coolant; 
- Wine material temperature;

- Wine material pressure.

Thus, analyzing akratofor terms of regulatory challenges, we can say that it is necessary to construct a cascade system of automated pressure control wine material from the intermediate point temperature wine base and additional refrigerant temperature control loop.

Main part

Imagine a formal scheme of control object.

A necessary condition for the solution of control problems is the presence of control actions, which, of course, have to be input variables EI illustrative example is shown in Fig. 1.

Fig. 1 - Formalized parametric diagram of the controlled system

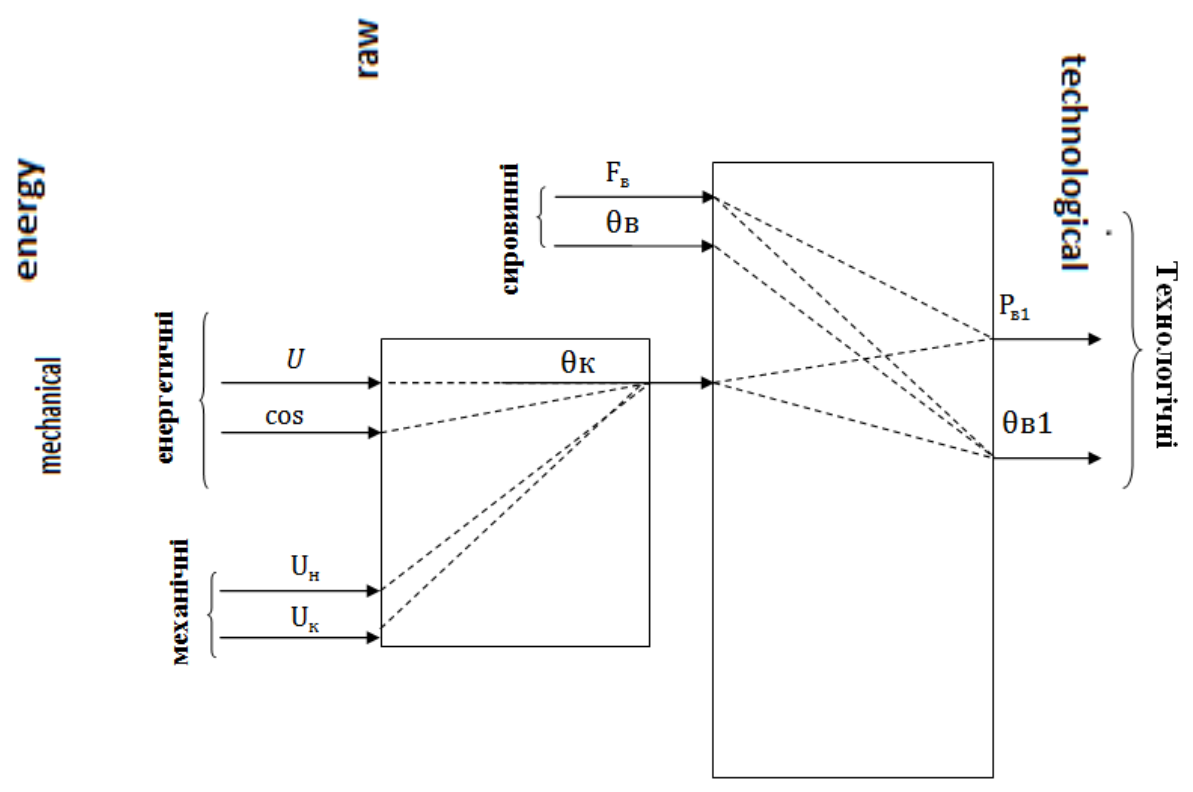

Fig. 1

The department provided a method of automatic control of the process raw wine fermentation akratofor comprising measuring and maintaining the setpoint temperature akratofor by changing the coolant flow rate, and measuring and maintaining the temperature of the refrigerant by changing the compressor speed, additional measurement and wine base temperature stabilization akratofor by changing the refrigerant flow is established given its importance to the wine material akratofor pressure would be equal to its setpoint.

Formalized coordinate process control scheme is shown in Figure 2

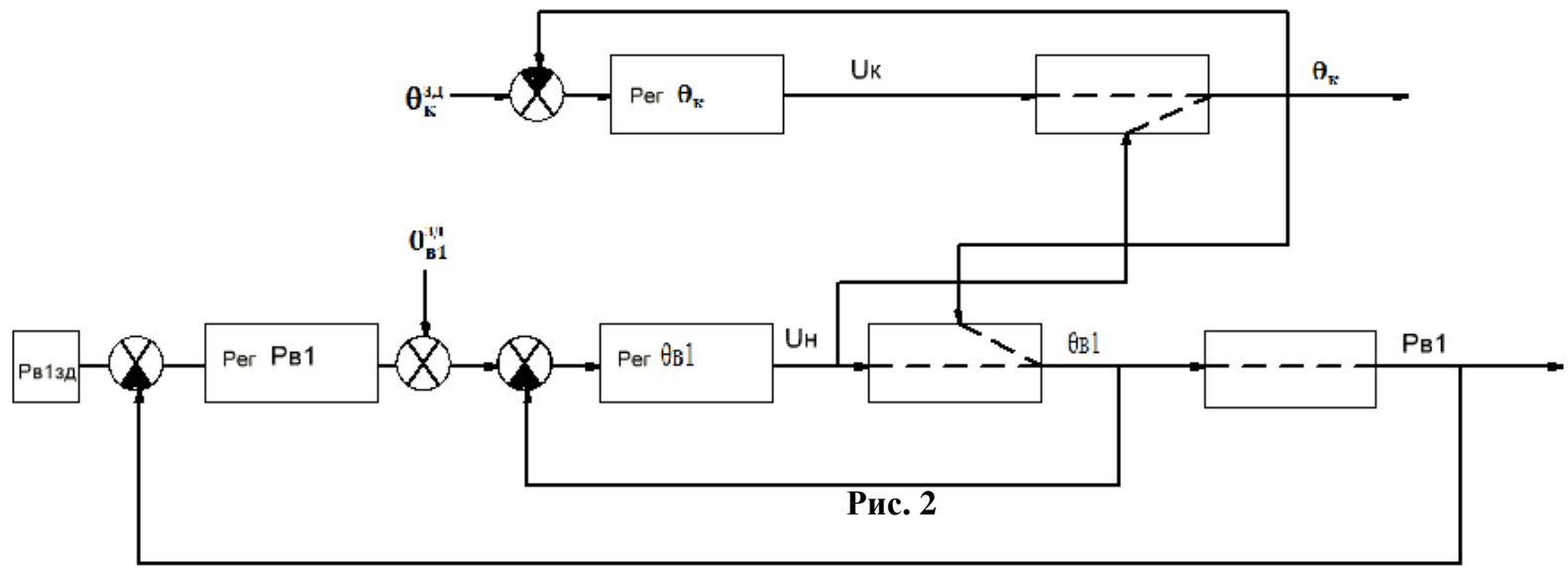

The scheme includes the following channels:

Channel ( $\mathrm{U} \mathrm{k}-\theta \mathrm{k})$ - compressor speed change affects the temperature of the coolant;

Channel (Un - $\theta v 1$ ) - Pump speed frequency change of the refrigerant flow affects the temperature of the wine base;

Channel (Un - $\theta \mathrm{k}$ ) - Pump speed frequency change of the refrigerant flow affects the temperature of the coolant; 
Channel ( $\theta \mathrm{v} 1$ - PB1) - wine material temperature affect the wine material pressure; Channel $(\theta \mathrm{k}-\theta \mathrm{v} 1)$ - coolant temperature affects the temperature of the wine base;

Fig. 3 - Graphs of transients controlled

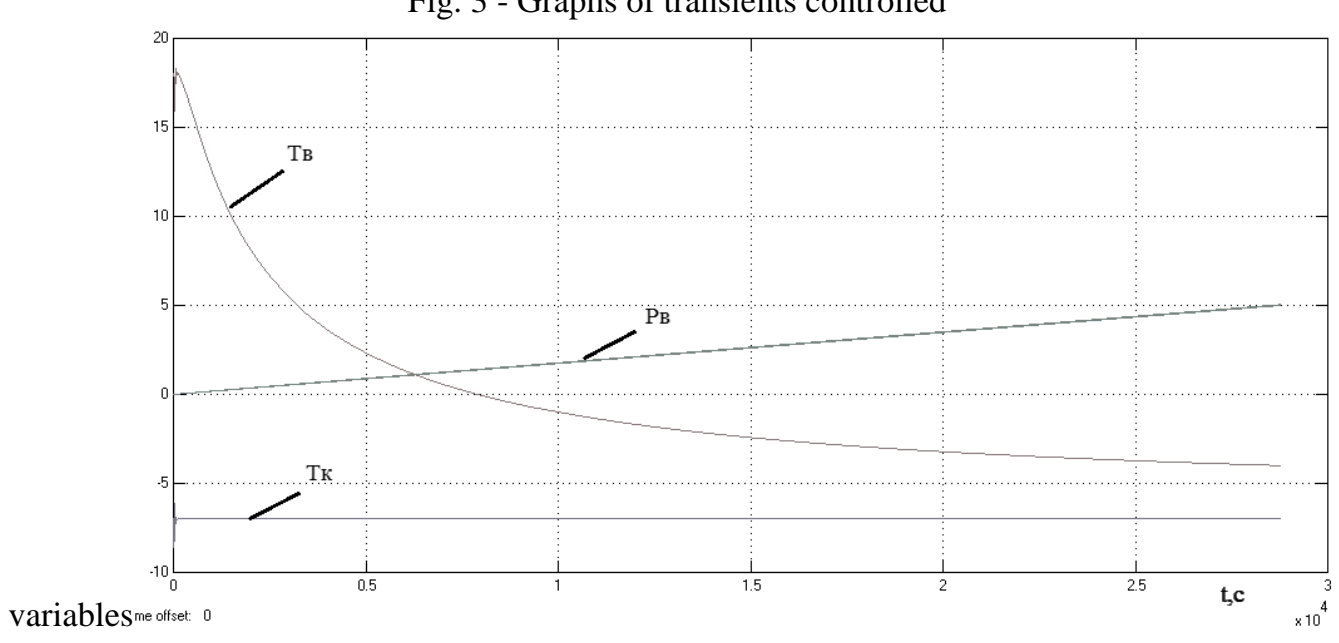

Fig. 3

Tc - temperature of the refrigerant at the outlet of Compressor

TV - wine material temperature in akratofor

PB - wine material pressure in akratofor

The graph shows the changes in the temperature of the wine material, and the pressure of the refrigerant increase in akratofor.

It was also designed operator station-system technology.

Operator workstation-technology must be capable of performing the operator the following functions:

- Control of process parameters values champagne process and task management regimes;

- Condition monitoring equipment installation (on, off, is in an accident, etc.) and the values of operating parameters of the installation;

- Control the start and stop of the installation manual and automatic control modes;

- To manage a separate installation of the equipment in manual mode;

- To monitor the occurrence of abnormal operation of equipment, and to respond quickly to them. Fig.4 AWP

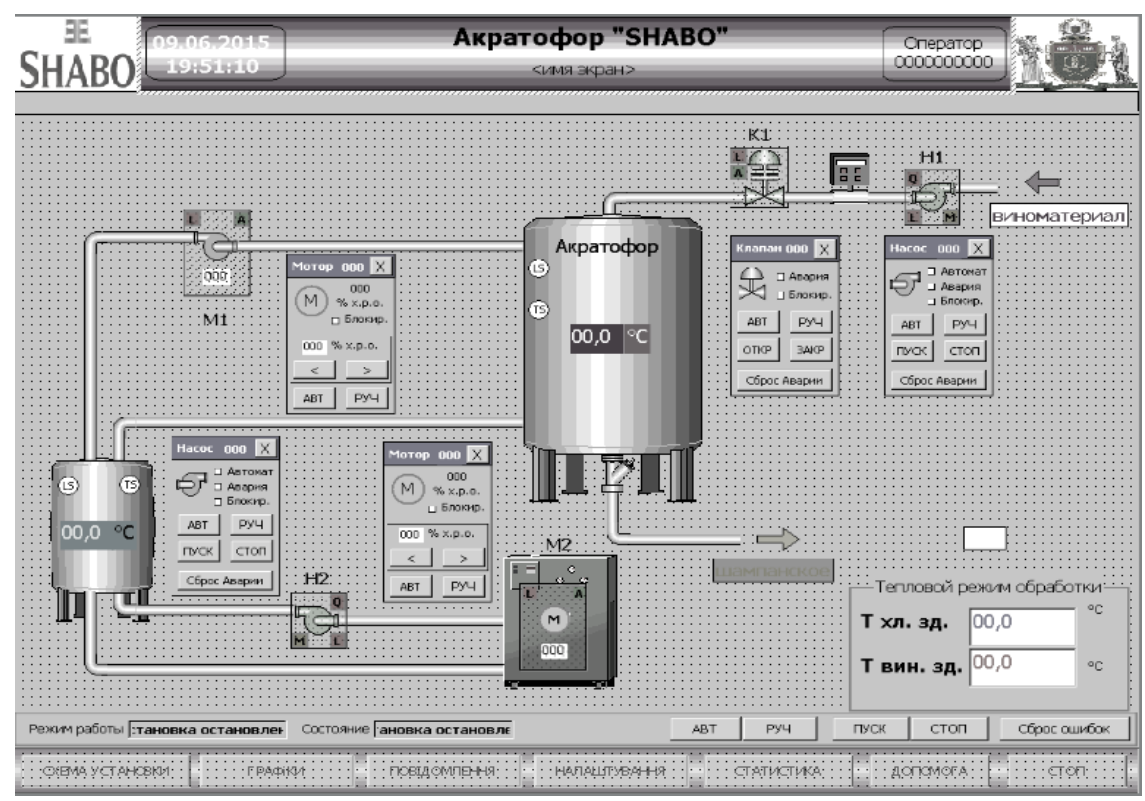

Fig.4 


\title{
Conclusions
}

-Development of system of automatic control of the process of champagne wines to install akratofor improves the quality of the finished product.

-To Improve performance in temperature control channel further measure temperature wine material and this information is used in a cascade ATS endpoint - the pressure of the wine material.

-Designed SCADA-system for process operators, allows you to monitor the progress of the process and manage the entire system from the operator's point.

\section{References}

[1] MetodichnI vkazIvki do vikonannya ta oformlennya kursovoYi roboti z distsiplIni «Teorlya avtomatichnogo keruvannya »dlya studentIv spetsIalnostey 7.092501 dennoYi ta zaochnoYi form navchannya / Avtor:V.A. HobIn - Odesa: ONAHT, 2000.

[2] Konspekt kursa lektsiy po distsipline "Teoriya avtomaticheskogo upravleniya" (chast I)- Hobin V.A. OGAPT. Odessa $2007 \mathrm{~g}$.

[3] Konspekt kursa lektsiy po distsipline "Teoriya avtomaticheskogo upravleniya" (chast II)- Hobin V.A. OGAPT. Odessa $2007 \mathrm{~g}$.

\section{GRAPH MODELING OF THE GRAIN PROCESSING ENTERPRISE FOR SECONDARY EXPLOSION ESTIMATIONS}

Popov A.S., post-graduate ${ }^{1}$

${ }^{1}$ Odessa National Academy of Food Technologies, Odessa

Copyright $\mathbb{C} 2014$ by author and the journal "Automation technological and business - processes". This work is licensed under the Creative Commons Attribution International License (CC BY). http://creativecommons.org/licenses/by/4.0/

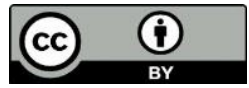

ONAFT

Open Access

DOI: $10.15673 /$

\begin{abstract}
Mathematical model for the possible development of the primary explosion at the grain processing enterprise is created. It is proved that only instability is possible for the combustion process. This model enables to estimate possibility of the secondary explosion at any object of the enterprise and forms the base for mathematical support of the decision support system for explosion-proof. Such decision support system can be included in the control system of the processing enterprise.
\end{abstract}

Keywords

Grain processing enterprise, explosion, secondary explosion, decision support system, control system, graph, fuzzy estimation, the shortest path in the graph.

Introduction

There are a lot of explosions at the grain processing enterprises all over the world every year. Numerous researches and investigations are dedicated to the problem of the prevention of primary explosions, but there are too little scientific works 